Article

\title{
Low- and High-Pressure Membrane Separation in the Production of Process Water for Coke Quenching
}

\author{
Anna Trusek*(D), Maciej Wajsprych and Andrzej Noworyta \\ Division of Bioprocess, Micro- and Nanoengineering, Department of Chemistry, Wroclaw University of Science \\ and Technology, Wybrzeze Wyspianskiego 27, 50-370 Wroclaw, Poland; maciej.wajsprych@gmail.com (M.W.); \\ andrzej.noworyta@pwr.edu.pl (A.N.) \\ * Correspondence: anna.trusek@pwr.edu.pl; Tel.: +48-71-320-2653
}

Citation: Trusek, A.; Wajsprych, M.; Noworyta, A. Low- and

High-Pressure Membrane Separation in the Production of Process Water for Coke Quenching. Membranes 2021, 11, 937. https://doi.org/10.3390/ membranes11120937

Academic Editors: Marek Gryta and Wojciech Kujawski

Received: 6 November 2021

Accepted: 25 November 2021

Published: 27 November 2021

Publisher's Note: MDPI stays neutral with regard to jurisdictional claims in published maps and institutional affiliations.

Copyright: (C) 2021 by the authors. Licensee MDPI, Basel, Switzerland. This article is an open access article distributed under the terms and conditions of the Creative Commons Attribution (CC BY) license (https:/ / creativecommons.org/licenses/by/ $4.0 /)$.
Abstract: Although the time for operating mines and coking plants in many countries is coming to an end due to climate change, we must still ensure that the pollution generated by this source of the economy is minimized. Despite the several stages of treatment of the coke-oven effluent, completed with nitrification and denitrification processes preceding final sedimentation, the stream obtained does not meet the requirements of water for coke quenching. That is why the stream after biodegradation and sedimentation was treated on membrane units to ensure water reusing in the coking plant. As the subjected stream contained both solid and dissolved pollutants, a two-stage system was proposed: low- and high-pressure membrane filtration. Industrial modules were tested on pilot units operating under industrial plant conditions. In the case of the ultrafiltration process, all the tested ultrafiltration modules fulfilled the primary task. All of them separated almost completely the turbidities present in the stream, which would have disturbed the operation of the high-pressure plant. Considering the decrease in permeate flux and the possibility of cleaning, a PCI membrane made of PVDF tubes with a diameter of $12.5 \mathrm{~mm}$ and pore size of $20 \mu \mathrm{m}$ was selected. Regarding the high-pressure membrane filtration, the reverse osmosis membrane was significantly better in the removal efficiency of both organic and inorganic dissolved substances. An operating pressure of $3 \mathrm{MPa}$ was chosen for the system. Hence, membrane processes, which are not used as stand-alone treatment units for coke-oven effluents, function well as a final treatment stage.

Keywords: coke-oven wastewater; membrane separation; water recovery; coke quenching

\section{Introduction}

Mine operation is seen as one of the causes of climate change. Over 40 countries, including Poland, committed to abandoning coal at the COP26 climate conference in Glasgow in November 2021. However, it is not a process that will take place overnight. Additionally, the declaration was not signed by several countries that are the world's most significant coal users. That is why today it remains necessary to create wise policies on exhaust gas treatment to protect the air and on wastewater management to reduce waste and ensure the water cycle in a plant.

Coking plants are a source of many hazardous substances produced during the coking of coal and the treatment of the resulting products [1,2]. The size of the wastewater stream, the multitude of present compounds, and their instability in time pose a problem for wastewater treatment. The required concentration values of individual compounds that can be discharged into surface waters are becoming increasingly stringent. They are most often referred to as phenolic wastewater due to the predominant content of this compound $[3,4]$. According to the place of generation, coking plant effluents can be divided into tar, gas cooling, benzol recovery, rectification, and tar processing. The primary chemical pollutants of coke oven effluents, apart from phenols, are organic compounds conventionally referred to as COD (chemical oxygen demand), ammonia, sulfides, and 
cyanides [5-7]. Their origin is mainly the installation of cooling and condensation of raw coke-oven gas leaving the coke-oven chambers.

A secondary condensate gas is obtained by repeated cooling. The collected condensate flows through a mechanical clarifier into the ammonia water tank. Further on, processes typical for coke-oven wastewater treatment plants take place. During extraction, the content of volatile phenols is reduced, and then the process of steam distillation for ammonia removal occurs. After tar removal, a coagulant containing iron ions $(+2$ and +3$)$ is added. The iron ions in an alkaline environment react with sulfides and cyanides and bound cyanides, precipitating them as sludge [8,9]. Free cyanides and sulfides must be removed entirely (concentration below $0.1 \mathrm{ppm}$ ) because their presence in solution decreases the activity of the activated sludge used in the following (biological) stage of wastewater treatment. Slightly more lenient conditions are for the reduction of the bound cyanide. Their concentration in wastewater undergoing biological treatment cannot exceed $5 \mathrm{ppm}$.

Activated sludge is responsible for the process of nitrification and denitrification $[10,11]$. The carbon source used by activated sludge microorganisms is phenol and its derivatives present in the wastewater. The content of the main components of coke-oven wastewater before and after the integrated treatment described above is presented in Table 1.

Table 1. Selected values for raw wastewater and after treatment with a final stage involving activated sludge [12].

\begin{tabular}{ccc}
\hline Parameter & Raw Wastewater $(\mathbf{m g} / \mathrm{L})$ & After Treatment $(\mathbf{m g} / \mathbf{L})$ \\
\hline COD & 6446 & $<250$ \\
Phenols & 1656 & $<0.1$ \\
Ammonium & 4349 & $<10$ \\
Complex cyanides & 20 & $<5$ \\
Thiocyanates & 401 & $<10$ \\
Salinity & 7946 & $<5623$ \\
Sulfides & 67 & $<0.1$ \\
\hline
\end{tabular}

The wastewater treated in this way is partly used in the water management of the coking plant. The quality of processes within the coking plant is strongly dependent on the quality of this water. The water used for coke quenching is the direct factor that ultimately determines the grade of the coke produced [13]. In practice, this is often utility water mixed with wastewater treated using the methods discussed above. The highest coke purity class can be obtained using water free of COD and desalinated, especially from chlorides and sulphates. For this reason, further purification of the final effluent to achieve water that is as free as possible from the components listed in Table 1 is a worthwhile task that leads to economic benefits.

A promising possibility to solve this problem is membrane processes application. The membrane techniques enable a deep purification of media containing suspended solids, molecules, and ions [14-17]. So far, membrane techniques have not found an industrial application in the treatment of coke-oven wastewater. Several reasons influence this state of affairs. First of all, coke-oven wastewater is a multi-component medium with variable and unstable compositions. In addition, the membranes are blocked by tarry substances, hence the need for their complete removal in the first stage of coke-oven effluent treatment and membrane regeneration during the process. Nevertheless, the stream obtained after chemical and microbiological purification, free from most impurities, can be subject to membrane separation.

In the literature regrading this subject, only a few papers can be found [18-23]. Kumar and Pal conducted a study on the filtration of coke-oven effluent using reverse osmosis and nanofiltration $[18,19]$. The experiments were carried out using flat modules and crossflow at varying parameters, such as pressure, linear velocity, and $\mathrm{pH}$ of the feed. During reverse osmosis, COD, cyanides, phenols, and ammonium nitrogen were removed with a $96-98 \%$ efficiency, at a maximum permeate flux of $46 \mathrm{~L} /\left(\mathrm{m}^{2} \cdot \mathrm{h}\right)$. Better results, $99 \%$ 
compound removing, was obtained at a similar permeate flux value $\left(45 \mathrm{~L} /\left(\mathrm{m}^{2} \cdot \mathrm{h}\right)\right.$ during the nanofiltration process.

Kwiecinska and Rychlewska et al. $[20,21]$ tested different types of polymeric, polyethersulfone membranes that differed in cut-off (equal to 20,10,5, and $3 \mathrm{kDa}$ ) and ceramic membranes with a zirconia active layer $(5$ and $8 \mathrm{kDa})$ to find the most efficient removal of complex cyanides and chemical oxygen demand (COD). The evaluation of processes was made on the basis of flux stability, fouling intensity, complex cyanides, and COD removal rates. The studies revealed that the ultrafiltration process enabled to remove complex cyanides up to $75 \%$, whereas COD was decreased by $27 \%$.

In experiments conducted by Jin et al. [22], nanofiltration and reverse osmosis were applied after a membrane bioreactor for biological treatment. The removals reached $82.5 \%$ (COD), 89.6\% (BOD), 99.8\% (ammonium nitrogen), 99.9\% (phenol), 44.6\% (total cyanide (T-CN)), 99.7\% (thiocyanide (SCN-)), and 8.9\% (fluoride) during the biological treatment stage. The nanofiltration-reverse osmosis system significantly reduced the parameters, including COD, T-CN, total nitrogen, fluoride, chloride ion, hardness, and conductivity, to a level suitable for industrial reuse, with a total water production ratio of $70.7 \%$.

The combination of biodegradation with membrane processes (reverse osmosis) has also been confirmed by Pimple et al. [23]. The final rejection of cyanide in the RO permeate was above $90 \%$, phenol above $95 \%$, and total suspended solids was $100 \%$. Thus, the permeate quality was found satisfactory and the process may be adopted at full-scale for treatment of coke-oven wastewater in the industry.

This work aimed to select the membrane processes and the membranes used in them so that the stream leaving the installation (final permeate) fully meets the requirements of process water, and more precisely, the water for coke quenching. In this way, the water from the mine could be fully recycled, which would directly impact the management of water resources. Due to the scale of the application, it was important that laboratoryscale research could be transferred to an industrial scale. Hence, the study was carried out on a sizeable laboratory-scale apparatus and commercially available membranes for large-scale purposes.

\section{Materials and Methods}

\subsection{Coke-Oven Wastewater}

The effluent used in the experiments was delivered directly after the biological treatment and sedimentation process by the selected coke plant in Poland (the name protected by contract); its characteristics are presented in Table 2. There is a high concentration of sulfates and chlorides. These came from $\mathrm{FeCl}_{3}$ and $\mathrm{Fe}_{2}\left(\mathrm{SO}_{4}\right)_{3}$, which are added during the preceding coagulation process. Moreover, the ratio of COD determined by the chromium method to BOD is high. It indicates that the organic content was well oxidized during biological treatment. The wastewater was brown, and the suspension tended to slow coagulation. 
Table 2. The average composition of the stream after the biological treatment and sedimentation process from a coke plant (the name protected by contract) in Poland (data received from the company).

\begin{tabular}{|c|c|c|c|}
\hline Parameter & Unit & Range & Mean Value \\
\hline $\mathrm{pH}$ & $\mathrm{pH}$ & $8.2-8.5$ & 8.4 \\
\hline Conductivity & $\mathrm{mS} / \mathrm{cm}$ & $11.3-12.1$ & 11.7 \\
\hline Total nitrogen & $\mathrm{mg} \mathrm{N} / \mathrm{L}$ & 50.5 & 50.5 \\
\hline Organic nitrogen & $\mathrm{mg} \mathrm{N}_{\text {org }} / \mathrm{L}$ & 6.4 & 6.4 \\
\hline Ammonia & $\mathrm{mg} \mathrm{N}_{\mathrm{NH} 4} / \mathrm{L}$ & $0.7-32.7$ & 16.7 \\
\hline Nitrate & $\operatorname{mg} \mathrm{N}_{\mathrm{NO} 3} / \mathrm{L}$ & $10.6-25.4$ & 18.0 \\
\hline Nitrite & $\mathrm{mg} \mathrm{N}_{\mathrm{NO} 2} / \mathrm{L}$ & 0.8 & 0.8 \\
\hline Phosphates & $\mathrm{mg} \mathrm{P} / \mathrm{L}$ & 4.1 & 4.1 \\
\hline Total phosphorus & $\mathrm{mg} \mathrm{P} / \mathrm{L}$ & 4.2 & 4.2 \\
\hline Oxygen dissolved & $\mathrm{mg} \mathrm{O}_{2} / \mathrm{L}$ & 8.9 & 8.9 \\
\hline BOD & $\mathrm{mg} \mathrm{O}_{2} / \mathrm{L}$ & 8.3 & 8.3 \\
\hline $\mathrm{COD}(\mathrm{Mn})$ & $\mathrm{mg} \mathrm{O}_{2} / \mathrm{L}$ & 165.8 & 165.8 \\
\hline $\operatorname{COD}(\mathrm{Cr})$ & $\mathrm{mg} \mathrm{O}_{2} / \mathrm{L}$ & $398-795$ & 617 \\
\hline Total hardness & $\mathrm{mg} \mathrm{CaCO}_{3} / \mathrm{L}$ & $339.3-857$ & 598.1 \\
\hline Alkalinity & $\mathrm{mg} \mathrm{CaCO}_{3} / \mathrm{L}$ & $550-700$ & 625 \\
\hline Turbidity & NTU & $4.7-34.5$ & 17.3 \\
\hline Sulfates & $\mathrm{mg} \mathrm{SO}_{4} / \mathrm{L}$ & $1663-1780.5$ & 1721.8 \\
\hline Chlorides & $\mathrm{mg} \mathrm{Cl} / \mathrm{L}$ & $3463-5150$ & 4306.5 \\
\hline Sodium & $\mathrm{mg} \mathrm{Na} / \mathrm{L}$ & $200.4-233.7$ & 217.0 \\
\hline Potassium & $\mathrm{mg} \mathrm{K} / \mathrm{L}$ & 8.9-11.6 & 10.3 \\
\hline Calcium & $\mathrm{mg} \mathrm{Ca} / \mathrm{L}$ & $28-78.7$ & 53.4 \\
\hline Magnesium & $\mathrm{mg} \mathrm{Mg} / \mathrm{L}$ & $5.6-17.2$ & 11.4 \\
\hline Manganese & $\mathrm{mg} \mathrm{Mn} / \mathrm{L}$ & 0.1 & 0.1 \\
\hline Iron & $\mathrm{mg} \mathrm{Fe} / \mathrm{L}$ & $1.9-5.1$ & 3.5 \\
\hline Color & $\mathrm{mg} / \mathrm{L}$ & $300-1560$ & 930 \\
\hline Total dry matter & $\mathrm{mg} / \mathrm{L}$ & 7730 & 7730 \\
\hline Mineral dry matter & $\mathrm{mg} / \mathrm{L}$ & 480 & 480 \\
\hline Organic dry matter & $\mathrm{mg} / \mathrm{L}$ & 7250 & 7250 \\
\hline TDS & $\mathrm{mg} / \mathrm{L}$ & 7540 & 7540 \\
\hline Mineral TDS & $\mathrm{mg} / \mathrm{L}$ & 365 & 365 \\
\hline Organic TDS & $\mathrm{mg} / \mathrm{L}$ & 7175 & 7175 \\
\hline Total suspension & $\mathrm{mg} / \mathrm{L}$ & 190 & 190 \\
\hline Mineral suspension & $\mathrm{mg} / \mathrm{L}$ & 115 & 115 \\
\hline Organic suspension & $\mathrm{mg} / \mathrm{L}$ & 75 & 75 \\
\hline
\end{tabular}

\subsection{Membrane Modules and Installations}

The modules used in this work were made in-house from commercially available membranes of varying selectivity. The module housings were made of PVC-U (Landefeld Druckluft und Hydraulik GmbH, Kassel-Industriepark, Germany). A number of membrane tubes was used in each module to ensure the required retentate flow rate ( $>4 \mathrm{~m} / \mathrm{s}$ ). The epoxy resin Epidian 5 (CMS Ltd., Gateshead, UK) and polyamide hardener Z1 (CMS Ltd., Gateshead, UK) at a ratio of 10:1 $w / w$ were used to glue the membranes. The module housings were glued using PVC-U materials from Georg-Fischer Ltd. (Schaffhausen, Switzerland).

The characteristics of the membranes and modules used in this study are presented in Table 3. Figure 1 presents the image of modules Nos. 1-4. 
Table 3. The parameters of the membrane modules used during this research.

\begin{tabular}{|c|c|c|c|c|c|c|c|c|c|}
\hline No & Type & Producer & Material & Selectivity & $\begin{array}{l}\text { Diameter } \\
(\mathrm{mm})\end{array}$ & $\begin{array}{l}\text { Length } \\
(\mathrm{mm})\end{array}$ & $\begin{array}{l}\text { No of } \\
\text { Tubes }\end{array}$ & $\begin{array}{l}\text { Area } \\
\left(\mathrm{m}^{2}\right)\end{array}$ & $\begin{array}{c}\text { Cross- } \\
\text { Section Area } \\
\left(\mathrm{m}^{2}\right)\end{array}$ \\
\hline 1 & UF & $\begin{array}{c}\text { Burkert CUT } \\
\text { Ingelfingenm, } \\
\text { Germany }\end{array}$ & PES & $50 \mathrm{kDa}$ & 8.0 & 795 & 3 & 0.059 & $5.03 \times 10^{-5}$ \\
\hline 2 & UF & $\begin{array}{c}\text { PCI } \\
\text { Hampshire, UK }\end{array}$ & PVDF & $20 \mathrm{kDa}$ & 12.5 & 795 & 2 & 0.062 & $1.23 \times 10^{-4}$ \\
\hline 3 & UF & $\begin{array}{l}\text { Katmaj, Herford, } \\
\text { Germany }\end{array}$ & PVDF & $500 \mathrm{kDa}$ & 12.5 & 795 & 2 & 0.062 & $1.23 \times 10^{-4}$ \\
\hline 4 & UF & $\begin{array}{c}\text { Berghof, } \\
\text { Leeuwarden, } \\
\text { The Netherlands }\end{array}$ & PVDF & $0.03 \mu \mathrm{m}$ & 8.0 & 950 & 13 & 0.310 & $5.03 \times 10^{-5}$ \\
\hline 5 & NF & $\begin{array}{c}\text { PCI } \\
\text { Hampshire, UK }\end{array}$ & PA & $\begin{array}{c}75 \% \\
\mathrm{CaCl}_{2}\end{array}$ & 12.5 & 300 & 2 & 0.024 & $1.23 \times 10^{-4}$ \\
\hline 6 & $\mathrm{RO}$ & $\begin{array}{c}\text { PCI } \\
\text { Hampshire, UK }\end{array}$ & PA & $99 \% \mathrm{NaCl}$ & 12.5 & 300 & 2 & 0.024 & $1.23 \times 10^{-4}$ \\
\hline
\end{tabular}

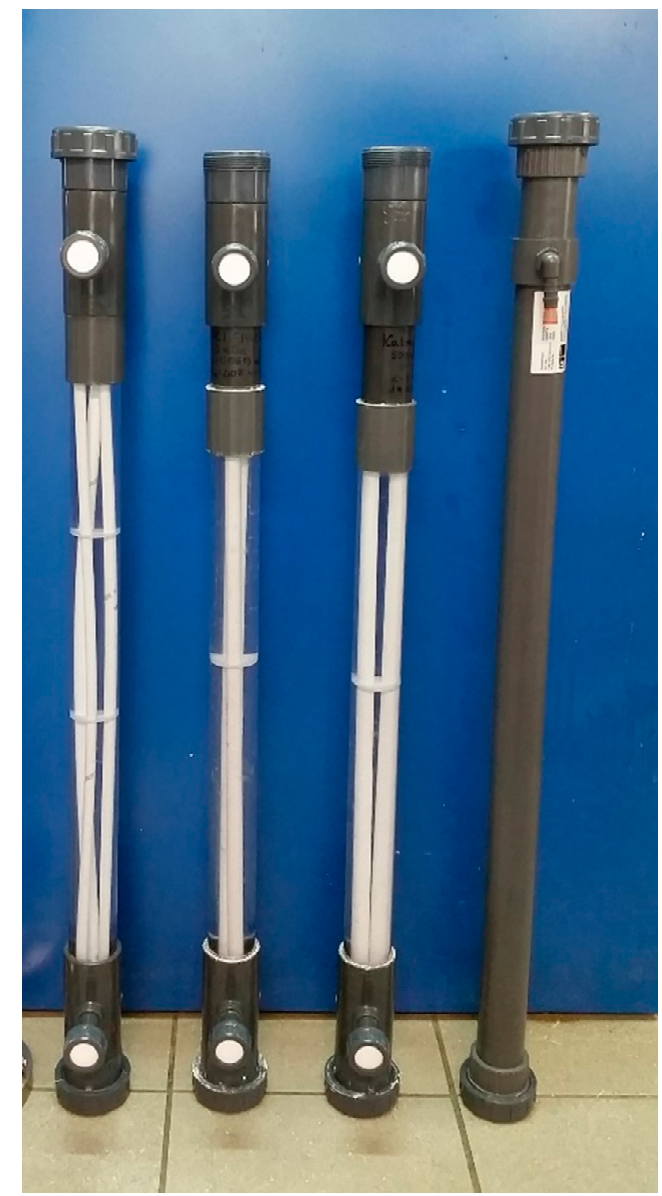

Figure 1. The modules used for low-pressure filtration.

The membranes differ in their selectivity, the material they are made of, and the range of process parameters at which they can be used. An important issue is the $\mathrm{pH}$ and temperature range because they determine the possible ways of carrying out the chemical regeneration of the membrane. The limit values of the working parameters of the membranes used in this study are summarized in Table 4. Methods for regeneration of the membranes used were described in an earlier publication by the authors [24]. 
Table 4. The limit values of the working parameters of the membranes.

\begin{tabular}{ccccccc}
\hline No & Type & Producer & Material & pH Range & $\begin{array}{c}\text { Maximum } \\
\text { Temperature }\left({ }^{\circ} \mathbf{C}\right)\end{array}$ & $\begin{array}{c}\text { Maximum } \\
\text { Pressure (MPa) }\end{array}$ \\
\hline 1 & UF & Burkert & PES & $2-11$ & 50 & 0.7 \\
2 & UF & PCI & PVDF & $1.5-10.5$ & 60 & 0.7 \\
3 & UF & Katmaj & PVDF & $1.5-10.5$ & 90 & 1.0 \\
4 & UF & Berghof & PVDF & $2-10$ & 40 & 0.6 \\
5 & NF & PCI & PA & $1.5-9.5$ & 60 & 6.0 \\
6 & RO & PCI & PA & $1.5-12$ & 80 & 6.4 \\
\hline
\end{tabular}

A Le Carbon Lorraine unit (Paris, France) and a Millipore installation (Burlington, MA, USA), presented in the Supplementary Materials, were used for the low- and high-pressure membrane filtration, respectively.

\subsection{Analytical Methods}

The process selectivity was estimated based on a few parameters such as COD, turbidity, color, alkalinity, and the concentration of selected cations and anions. All the analyses were carried out following the applicable procedures of the Polish Standardization Committee and are presented in Table 5. All the reagents used were of analytical grade and were purchased from Pol-Aura (Dywity, Poland).

Table 5. The methods for the selected parameters' determination.

\begin{tabular}{cccc}
\hline Parameter & Kind of Method & Procedure & Equipment \\
\hline COD & Titration method & PN-ISO 6060:2006 & $\begin{array}{c}\text { Titrator Compact G20S, } \\
\text { Mettler Toledo }\end{array}$ \\
\hline Turbidity & $\begin{array}{c}\text { Nephelometric } \\
\text { method }\end{array}$ & PN-EN ISO 7027:2016 & $\begin{array}{c}\text { Turbidity Meter TB1000 } \\
\text { Thermo Scientific }\end{array}$ \\
\hline Color & $\begin{array}{c}\text { Spectrophotometric } \\
\text { method }\end{array}$ & PN-EN ISO 7887:2002 & $\begin{array}{c}\text { Spectrophotometer } \\
\text { UV-1800 Shimadzu }\end{array}$ \\
\hline Alkalinity & Titration method & PN-EN ISO & $\begin{array}{c}\text { Titrator Compact G20S, } \\
\text { Mettler Toledo }\end{array}$ \\
\hline $\begin{array}{c}\text { Total nitrogen } \\
\text { Iron }\end{array}$ & Kjedahl method & PN-EN 25663:2001 & $\begin{array}{c}\text { Titrator Compact G20S, } \\
\text { Mettler Toledo }\end{array}$ \\
\hline $\begin{array}{c}\text { Pagnesium } \\
\text { Sotassium }\end{array}$ & Atomic Absorption \\
Spectrometry & Podium & & $\begin{array}{c}\text { ASA ICE3000 } \\
\text { Thermo Scientific }\end{array}$ \\
\hline Chlorides & Titration method & PN-ISO 9297:1994 & $\begin{array}{c}\text { Titrator Compact G20S, } \\
\text { Mettler Toledo }\end{array}$ \\
\hline $\begin{array}{c}\text { Phosphates } \\
\text { Sulfates }\end{array}$ & $\begin{array}{c}\text { Spectrophotometric } \\
\text { method }\end{array}$ & PN-ISO 6878/1:2006 & $\begin{array}{c}\text { Spectrophotometer } \\
\text { UV-1800 Shimadzu }\end{array}$ \\
\hline Gravimetric method & PN-ISO 9280:2002 & $\begin{array}{c}\text { Analytical balance AS } \\
\text { 160.R2 Radwag }\end{array}$ \\
\hline
\end{tabular}

\section{Results}

The treatment of coke-oven streams after biological treatment and sedimentation was divided into two stages: pre-treatment by low-pressure membrane filtration and deep treatment by high-pressure filtration. 


\subsection{Low-Pressure Membrane Filtration}

Four different ultrafiltration membranes were used in the study. The hydraulic characteristics of these membranes were described in an earlier publication by the authors [24]. Based on these data, a pressure of $0.2 \mathrm{MPa}$ was chosen for the study on contaminant separation.

A speedy decrease in the permeate flux was observed for each of them during the first few minutes, followed by a period of pseudo-stable operation of the system (Figure 2). The permeate flux obtained during this period was in the range of $120-210 \mathrm{~L} /\left(\mathrm{m}^{2} \cdot \mathrm{h}\right)$. The degree of feed concentration slightly affected the permeate flux change profile (example curves, for the PCI membrane, are presented in Figure 3).

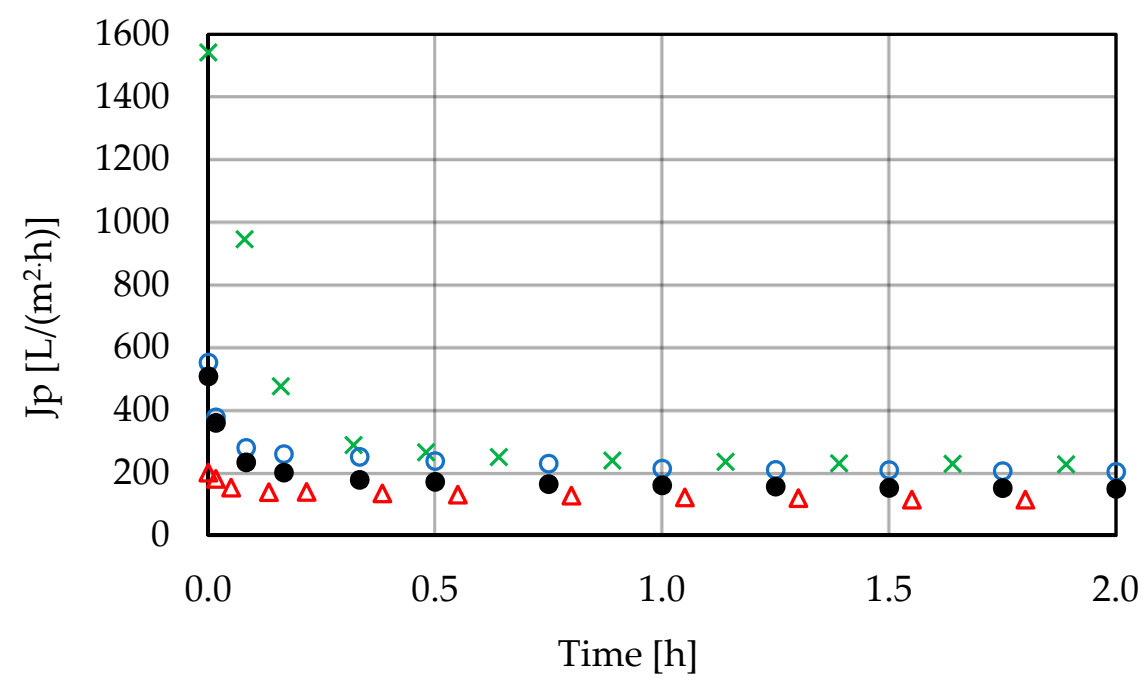

Figure 2. Change in permeate flux during low-pressure filtration $\left(\mathrm{T}=25^{\circ} \mathrm{C}, \mathrm{w}=4 \mathrm{~m} / \mathrm{s}, \Delta \mathrm{P}=0.2 \mathrm{MPa}\right)$; $\times$, Berghof $0.03 \mathrm{~mm}$; o, Katmaj $500 \mathrm{kDa}, \Delta$, Burkert CUT $50 \mathrm{kDa}$ •, PCI $20 \mathrm{kDa}$. Points represent the average of five measurements.

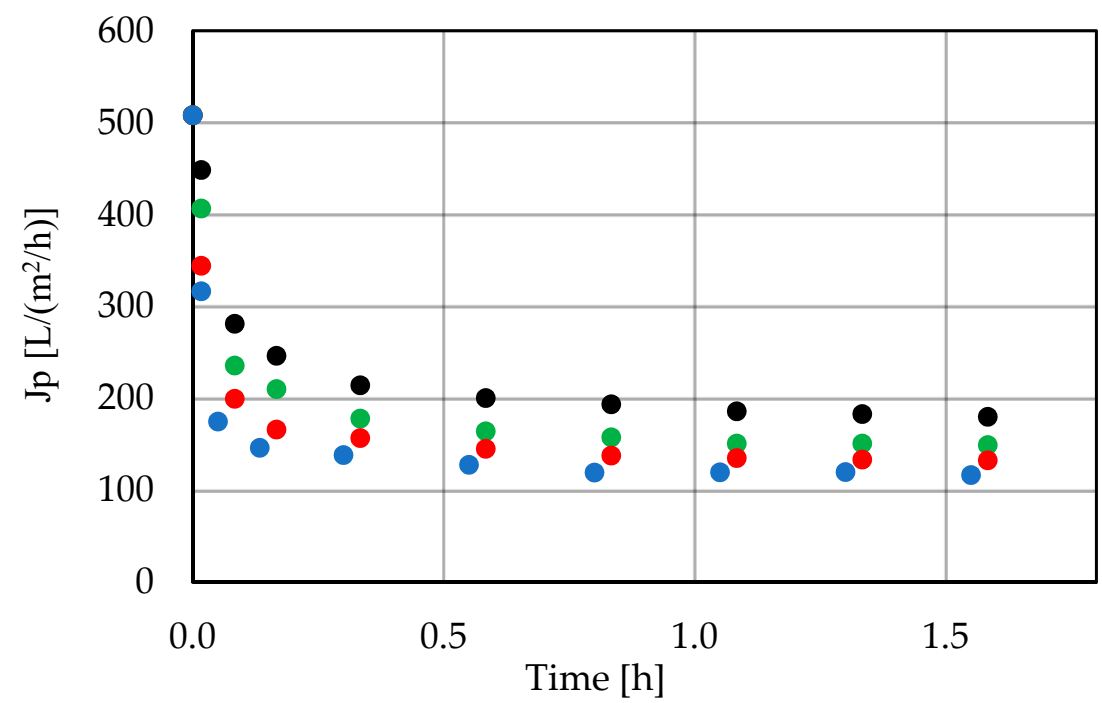

Figure 3. Change in permeate flux during low-pressure filtration for the PCI $20 \mathrm{kDa}$ membrane $\left(\mathrm{T}=25{ }^{\circ} \mathrm{C}, \mathrm{w}=4 \mathrm{~m} / \mathrm{s}, \Delta \mathrm{P}=0.2 \mathrm{MPa}\right)$ using the initial feed $(\bullet)$ and $2(\bullet), 4(\bullet)$, and $6(\bullet)$ times concentrated feeds. Points represent the average of five measurements.

Samples for analysis of the obtained permeates were taken in a pseudo-stationary state (after one hour). The composition of the feed varied from experiment to experiment, 
which is due to the variability in the coke-oven effluents. The permeate quality obtained for all the membranes tested was similar although the pore size varied considerably (Table 6).

Table 6. Degree of removal of the selected components during low-pressure filtration $\left(\mathrm{T}=25^{\circ} \mathrm{C}, \mathrm{w}=4 \mathrm{~m} / \mathrm{s}, \Delta \mathrm{P}=0.2 \mathrm{MPa}\right)$.

\begin{tabular}{|c|c|c|c|c|c|c|}
\hline Parameter & Unit & & Berghof $0.03 \mu \mathrm{m}$ & Katmaj 500 kDa & CUT 50 kDa & PCI 20 kDa \\
\hline \multirow{3}{*}{ COD } & \multirow{2}{*}{$\mathrm{mg} \mathrm{O}^{2} / \mathrm{L}$} & Feed & $479 \pm 13$ & $795 \pm 16$ & $540 \pm 12$ & $498 \pm 12$ \\
\hline & & Permeate & $289 \pm 11$ & $578 \pm 13$ & $367 \pm 10$ & $384 \pm 13$ \\
\hline & $\%$ removal & & $39.7 \pm 2.4$ & $27.3 \pm 2.3$ & $32.0 \pm 1.9$ & $22.9 \pm 2.6$ \\
\hline \multirow{3}{*}{ Turbidity } & \multirow{2}{*}{ NTU } & Feed & $32.2 \pm 1.41$ & $12.6 \pm 0.81$ & $34.5 \pm 2.36$ & $18.6 \pm 0.74$ \\
\hline & & Permeate & $0.28 \pm 0.08$ & $0.38 \pm 0.07$ & $1.15 \pm 0.11$ & $0.23 \pm 0.09$ \\
\hline & $\%$ removal & & $99.1 \pm 0.4$ & $97.0 \pm 0.48$ & $96.7 \pm 0.39$ & $98.8 \pm 0.68$ \\
\hline \multirow{3}{*}{ Color } & \multirow{2}{*}{$\mathrm{mg}_{\mathrm{Pt}} / \mathrm{L}$} & Feed & $2050 \pm 154$ & $1560 \pm 87$ & $300 \pm 22$ & $1840 \pm 102$ \\
\hline & & Permeate & $736 \pm 77$ & $750 \pm 64$ & $150 \pm 19$ & $830 \pm 82$ \\
\hline & $\%$ removal & & $64.1 \pm 3.8$ & $51.9 \pm 3.4$ & $50.0 \pm 2.7$ & $54.9 \pm 3.3$ \\
\hline \multirow{3}{*}{ Iron } & \multirow{2}{*}{$\mathrm{mg}_{\mathrm{Fe}} / \mathrm{L}$} & Feed & $6.22 \pm 0.43$ & $1.93 \pm 0.20$ & $5.05 \pm 0.36$ & $2.7 \pm 0.27$ \\
\hline & & Permeate & $0.24 \pm 0.04$ & $0.150 \pm 0.02$ & $0.17 \pm 0.02$ & $0.14 \pm 0.01$ \\
\hline & $\%$ removal & & $96.1 \pm 0.54$ & $92.2 \pm 0.33$ & $96.6 \pm 0.58$ & $94.8 \pm 0.81$ \\
\hline \multirow{3}{*}{ Calcium } & \multirow{2}{*}{$\mathrm{mg} \mathrm{Ca}_{\mathrm{Ca}} / \mathrm{L}$} & Feed & $107.1 \pm 3.64$ & $100.5 \pm 4.48$ & $78.8 \pm 2.33$ & $94.7 \pm 3.49$ \\
\hline & & Permeate & $100 \pm 2.99$ & $95.7 \pm 3.02$ & $68.1 \pm 2.14$ & $91.6 \pm 3.19$ \\
\hline & $\%$ removal & & $6.6 \pm 2.74$ & $4.8 \pm 2.29$ & $13.6 \pm 4.28$ & $3.3 \pm 1.86$ \\
\hline
\end{tabular}

\subsection{High-Pressure Membrane Filtration}

The high-pressure filtration process was carried out with polyamide membranes, distinguished by the manufacturer (PCI) as nanofiltration $\left(75 \% \mathrm{CaCl}_{2}\right.$ retention) and reverse osmosis $\left(99 \% \mathrm{CaCl}_{2}\right.$ retention). The feed in these processes was the permeate obtained during ultrafiltration on the PCI $20 \mu \mathrm{m}$ membrane. High-pressure membrane filtration was carried out at transmembrane pressures of 1-3 MPa, at a temperature of $25^{\circ} \mathrm{C}$ for a period of $24 \mathrm{~h}$. The change in permeate flux over time is presented in Figures 4 and 5.

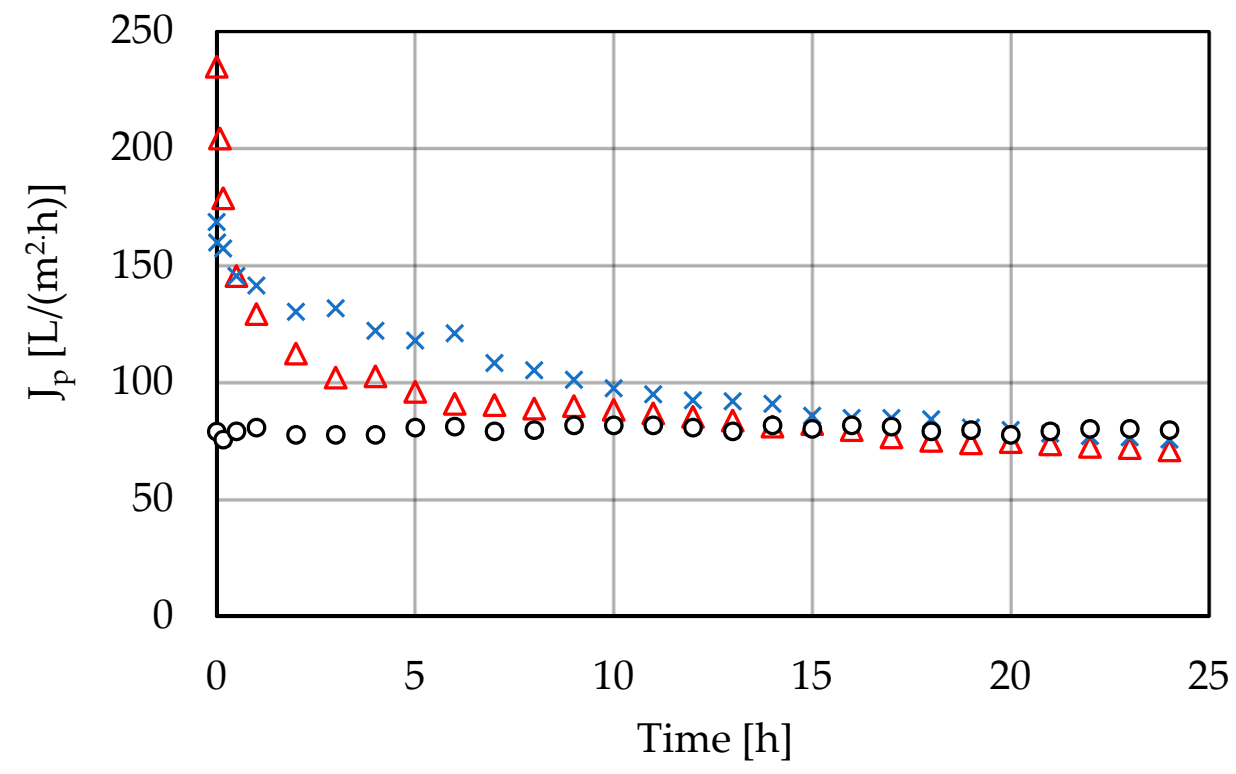

Figure 4. Permeate flux change during the nanofiltration process; PCI NF membrane, $\mathrm{T}=25^{\circ} \mathrm{C}$ (o, 1.0 MPa; $\times, 2.0 \mathrm{MPa} ; \Delta, 3.0 \mathrm{MPa}$ ). Points represent the average of five measurements. 


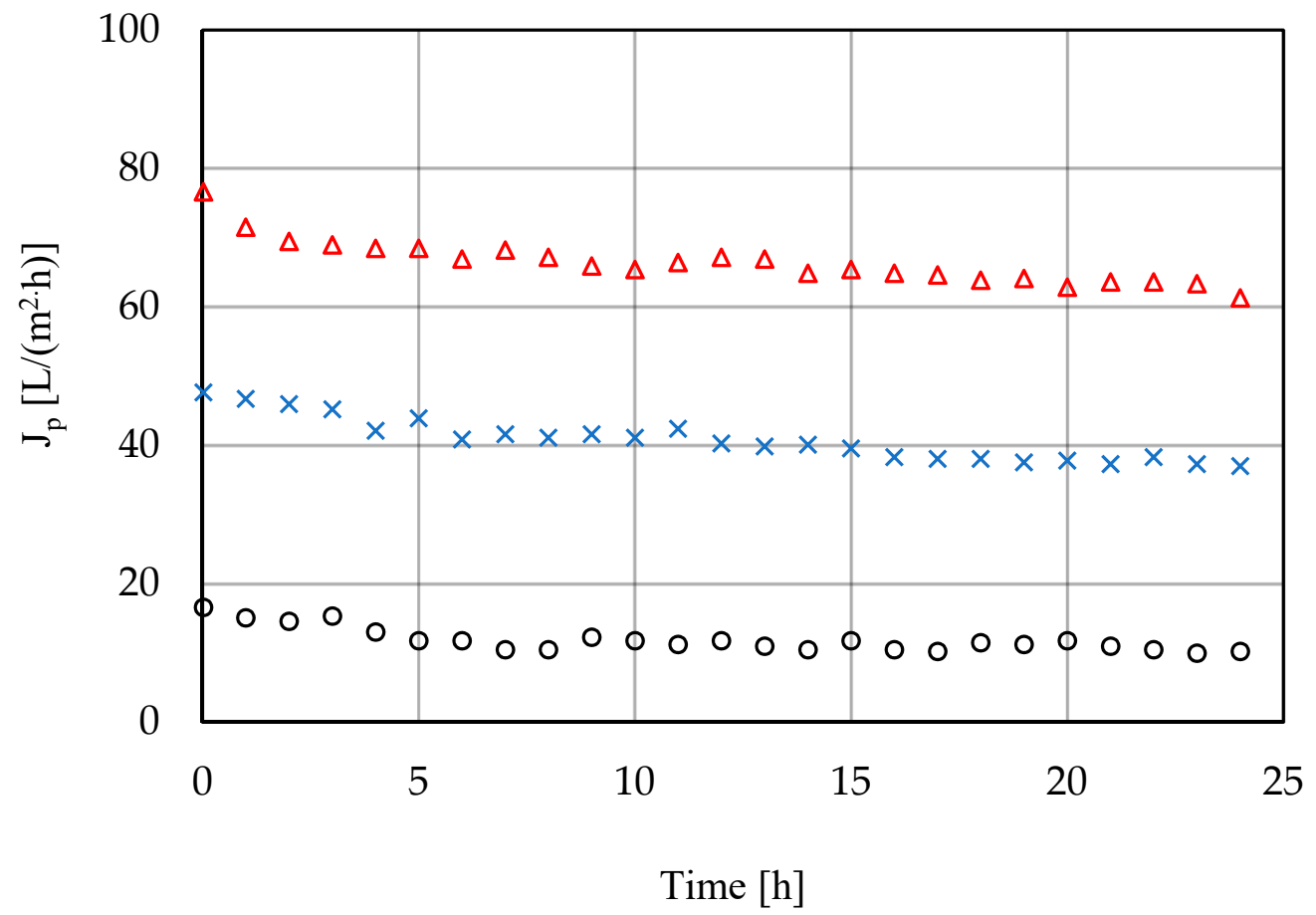

Figure 5. Permeate flux change during the reverse osmosis process; PCI RO membrane, $\mathrm{T}=25{ }^{\circ} \mathrm{C}(\mathrm{o}$, 1.0 MPa; $\times, 2.0 \mathrm{MPa} ; \Delta, 3.0 \mathrm{MPa}$ ). Points represent the average of five measurements.

The removal efficiency of the selected compounds during high-pressure filtration, expressed as the concentration of a given compound in the permeate to its concentration in the feed, is shown in Figure 6.

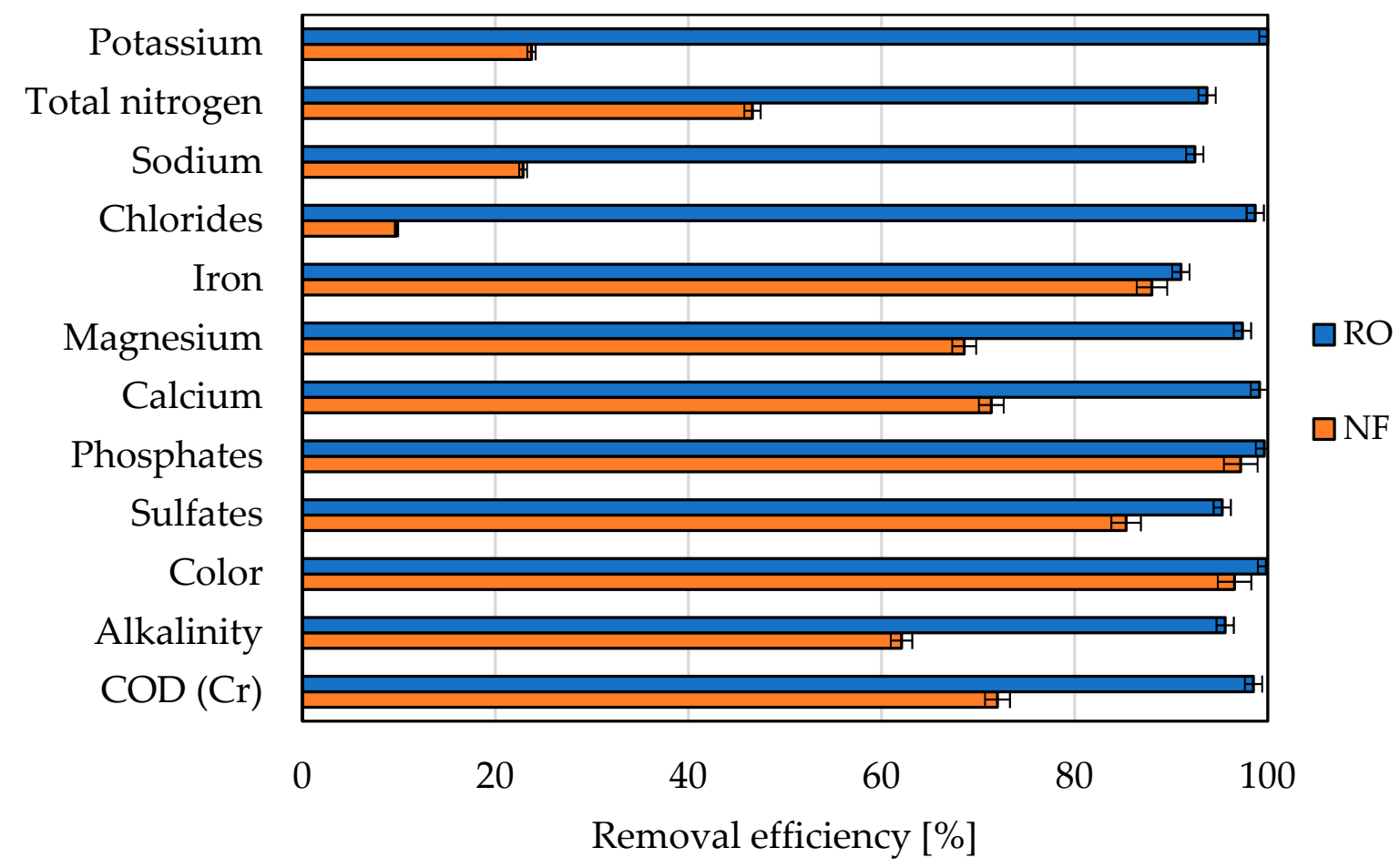

Figure 6. The removal efficiency of the selected compounds during high-pressure filtration; PCI NF membrane and PCI RO membrane, $\mathrm{T}=25^{\circ} \mathrm{C}, \Delta \mathrm{P}=3.0 \mathrm{MPa}$. 


\section{Discussion}

Although the membranes used in ultrafiltration differed significantly in pore size (from $0.03 \mathrm{~mm}$ to $20 \mathrm{kDa}$ ), the decrease in permeate flux and separation capacity were similar for all membranes. The ultrafiltration process was mainly considered to remove solids (turbidity), which would cause unstable operation of the high-pressure filtration plant. The effect of eliminating other components was taken as an additional benefit. It was obtained at a relatively high level for color compounds (more than $50 \%$ removal) and oxygenation compounds (COD parameter higher than 20\%). With the highest degree of turbidity removal in mind, two membranes can be selected: Berghof $0.03 \mu \mathrm{m}$ and PCI $20 \mathrm{kDa}$. The high solids separation involving a membrane with a pore size of $0.03 \mu \mathrm{m}$ is a surprising result. Particle size analysis (presented in the Supplementary Materials) performed with the Sald-2300 apparatus (Shimadzu, Kyoto, Japan) indicated that the size spread of the solid particles present in the coke-oven wastewater is between 0.027 and $0.063 \mu \mathrm{m}$, and the dominant fraction at about $0.04 \mu \mathrm{m}$. Analyzing the membrane material, PVDP was slower to block than PES. Both membranes indicated are made of PVDF. Due to the flow hydrodynamics and ease of cleaning, the larger-diameter tubes (20 kDa PCI membrane) appear to be a better choice. Independent studies developed a method for its regeneration after using in the treatment of mine wastewater [24].

The actual (final) separation took place during the high-pressure processes. The unfulfilled requirements after a biodegradation process for the process water for coke quenching mainly concerned COD and salination, especially coming from chlorides and sulphates. As expected, membrane separation using a reverse osmosis membrane was much more effective than separation using a nanofiltration membrane in terms of selectivity. The greatest differences were observed for monovalent ions, including chlorides, according to the theory of membrane processes and previous studies [25-27]. Removal of COD in the NF process was at a relatively low, unexpected level (approx. 73\%). Since high flux drops were observed for the NF membrane at all pressures tested, in contrast to the separation for the RO membrane, the high energy expenditure, a widely recognized result due to the use of higher pressures for the reverse osmosis process, was in this case practically the same as for the NF membrane. At a pressure of $3 \mathrm{MPa}$, after $24 \mathrm{~h}$, the permeate flux for both membranes was similar.

As the separation properties of the PCI RO membrane were significantly higher (for all compounds, the removal above $90 \%$ ), this membrane is recommended for mine wastewater treatment. The content of all compounds is low enough that the water obtained after reverse osmosis can be directly used for coke quenching.

The use of retentates (waste streams) was not undertaken in the presented research, but it is crucial to consider in further studies. Especially, the retentate after the ultrafiltration process, which is rich in organic matter, should be managed following the principle of clean technologies. As it is a stream with a dominant water fraction, its treatment could start with hydrothermal treatment, as was described for another aqueous waste stream [28].

Different processes, with their advantages and limitations, regarding energy and material cycling for sustainable solid waste management are presented in many papers [29-32]. They can be the base to develop a management technology for solids coming from cokeoven wastewater.

\section{Conclusions}

The use of membrane processes fully closes the water cycle in the mine, which allows for a significant improvement in water management. Using two-stage membrane separation, process water within the parameters for direct use in coke quenching processes was obtained.

Based on the research, the stream obtained after biodegradation and sedimentation should be subjected first to ultrafiltration and then reverse osmosis. For ultrafiltration processes, it is recommended to work with the membrane PCI $20 \mathrm{kDa}$, at $0.2 \mathrm{MPa}$. Due to the substantial flux drop during filtration, frequent regeneration of this membrane is 
necessary. In previously described studies [24], cleaning with sponge balls was selected for the PCI membrane. To remove dissolved organic (and thus COD) and inorganic compounds, it is recommended to use the PCI RO $(99 \% \mathrm{NaCl}$ retention) membrane at $3 \mathrm{MPa}$. Membrane operation under these conditions is stable for at least one day, after which a short-term backflushing is recommended. The research carried out on industrial membranes significantly reduce the amount of verification testing needed on the target plant. Its design can be done based on the presented results.

Supplementary Materials: The following are available online at https: / www.mdpi.com/article / 10.3390/membranes11120937/s1, Figure S1. The pilot installation of Le Carbon Lorraine for low pressure driven membrane filtration: 1 -feed water tank, 2-membrane module, 3-recirculation pump, 4-valve, 5-backflushing system, 6-compressor, 7-weight. Figure S2. The pilot installation of Millipore for high pressure membrane filtration; 1 -membrane module, 2-membrane pump, 3-tank. Figure S3. The size of solids in coke oven wastewater analyzed with Sald 2300 (Shimadzu, Kyoto, Japan).

Author Contributions: Conceptualization, A.N. and A.T.; methodology, A.N. and M.W; software, M.W.; validation, A.T.; formal analysis, A.N.; investigation, M.W.; resources, A.N. and A.T.; data curation, M.W.; writing —original draft preparation, M.W. and A.T.; writing-review and editing, A.N. and A.T.; visualization, M.W. and A.T.; supervision, A.N.; project administration, A.N.; funding acquisition, A.N. All authors have read and agreed to the published version of the manuscript.

Funding: This research was funded by the INNOWATREAT Research Fund for Coal and Steel under grant agreement No. 710078.

Institutional Review Board Statement: Not applicable.

Informed Consent Statement: Not applicable.

Data Availability Statement: Not applicable.

Conflicts of Interest: The authors declare no conflict of interest.

\section{References}

1. Maiti, D.; Ansari, I.; Rather, M.A.; Deepa, A. Comprehensive review on wastewater discharged from the coal-related industriesCharacteristics and treatment strategies. Water Sci. Technol. 2019, 79, 2023-2035. [CrossRef] [PubMed]

2. Mishra, L.; Paul, K.K.; Jena, S. Characterization of coke oven wastewater. In IOP Conference Series-Earth and Environmental Science; Eguchi, K., Quanrud, D., Takagi, H., Eds.; IOP Publishing: Bristol, UK, 2018; Volume 167. [CrossRef]

3. Rai, A.; Gowrishetty, K.K.; Singh, S.; Chakrabarty, J.; Bhattacharya, P.; Dutta, S. Simultaneous bioremediation of cyanide, phenol, and ammoniacal-N from synthetic coke oven wastewater using Bacillus sp. NITD 19. J. Environ. Eng. 2021, 147, 04020143. [CrossRef]

4. Elawwad, A.; Naguib, A.; Abdel-Halim, H. Modeling of phenol and cyanide removal in a full-scale coke oven wastewater treatment plant. Desalination Water Treat. 2016, 57, 25181-25193. [CrossRef]

5. Singh, H.; Mishra, B.K. Degradation of cyanide, aniline and phenol in pre-treated coke oven wastewater by peroxide assisted electro-oxidation process. Water Sci. Technol. 2018, 78, 2214-2227. [CrossRef]

6. Tyagi, M.; Kumari, N.; Jagadevan, S. A holistic Fenton oxidation-biodegradation system for treatment of phenol from coke oven wastewater: Optimization, toxicity analysis and phylogenetic analysis. J. Water Proc. Eng. 2020, 37, 101475. [CrossRef]

7. Pillai, I.M.S.; Gupta, A.K. Anodic oxidation of coke oven wastewater: Multiparameter optimization for simultaneous removal of cyanide, COD and phenol. J. Environ. Manag. 2016, 176, 45-53. [CrossRef]

8. Yngard, R.A.; Sharma, V.K.; Filip, J.; Zboril, R. Ferrate(VI) oxidation of weak-acid dissociable cyanides. Environ. Sci. Technol. 2008, 42, 3005-3010. [CrossRef] [PubMed]

9. Kwiecinska-Mydlak, A.; Sajdak, M.; Rychlewska, K.; Figa, J. The role of a chemical loop in removal of hazardous contaminants from coke oven wastewater during its treatment. Open Chem. 2019, 17, 1288-1300. [CrossRef]

10. Maneesh, N.; Bhuvanesh, S.; Shaikh, Z.A.; Sreekrishnan, T.R.; Mazumdar, S.M.; Mitra, C.M. Three-stage biological system for treatment of coke oven effluent. J. Hazard. Toxic Radioact. Waste 2018, 22, 04018012. [CrossRef]

11. Walter, B.; Haase, C.; Rabiger, N. Combined nitrification/denitrification in a membrane reactor. Water Res. 2005, 39, 2781-2788. [CrossRef] [PubMed]

12. Best Available Techniques (BAT) Guidelines for the Coking Industry; Ministry of the Environment: Warsaw, Poland, 2005. (In Polish)

13. Kwiecinska, A.; Figa, J.; Stelmach, S. The impact of cooling water parameters on the wet-quenched coke quality. Coke Chem. 2014, 57, 425-428. [CrossRef] 
14. Lech, M.; Niesobska, A.; Trusek-Holownia, A. Dairy wastewater utilization:separation of whey proteins in membrane and chromatographic processes. Desalination Water Treat. 2016, 57, 23326-23334. [CrossRef]

15. Pratofiorito, G.; Horn, H.; Saravia, F. Impact of the recovery on concentrating acetic acid with low-pressure reverse-osmosis membranes. Membranes 2021, 11, 742. [CrossRef]

16. Trusek-Holownia, A.; Noworyta, A. Two-step of harmful industrial wastewater: An analysis of microbial reactor with integrated membrane retention for benzene and toluene removal. Pol. J. Chem. Technol. 2015, 17, 15-22. [CrossRef]

17. Lee, J.; Na, J.; Baek, Y. Effects of impurities from sugar excipient on filtrate flux during ultrafiltration and diafiltration process. Membranes 2021, 11, 775. [CrossRef]

18. Kumar, R.; Pal, P. Removal of phenol from coke oven wastewater by Cross-Flow Nanofiltration Membranes. Water Environ. Res. 2013, 85, 447-455. [CrossRef] [PubMed]

19. Kumar, R.; Pal, P. A novel forward osmosis-nanofiltration integrated system for coke oven wastewater reclamation. Chem. Eng. Res. Design. 2015, 100, 542-553. [CrossRef]

20. Kwiecinska, A.; Kochel, M.; Rychlewska, K.; Figa, J. The use of ultrafiltration in enhancement of chemical coke oven wastewater treatment. Desalination Water Treat. 2018, 128, 214-221. [CrossRef]

21. Rychlewska, K.; Kwiecinska, A.; Kochel, K.; Figa, J. The use of polymeric and ceramic ultrafiltration in biologically treated coke oven wastewater polishing. Desalination Water Treat. 2018, 128, 207-213. [CrossRef]

22. Jin, X.; Li, E.; Lu, S.; Qiu, Z.; Sui, A. Coking wastewater treatment for industrial reuse purpose: Combining biological processes with ultrafiltration, nanofiltration and reverse osmosis. J. Environ. Sci. 2013, 25, 1565-1574. [CrossRef]

23. Pimple, S.; Karikkat, S.; Devanna, M.; Yanamadni, V.; Sah, R.; Prasad, S.M.R. Comparison of MBR/RO and UF/RO hybrid systems for the treatment of coke-oven effluents. Desalination Water Treat. 2016, 57, 3002-3010. [CrossRef]

24. Trusek, A.; Wajsprych, M.; Tyrka, M.; Noworyta, A. Regeneration methods of the ultrafiltration membranes applied in coke oven wastewater treatment. Desalination Water Treat. 2021, 214, 120-127. [CrossRef]

25. Van der Bruggen, B.; Koninckx, A.; Vandecasteele, C. Separation of monovalent and divalent ions from aqueous solution by electrodialysis and nanofiltration. Water Res. 2004, 38, 1347-1353. [CrossRef]

26. Pérez-González, A.; Ibáñez, R.; Gómez, P.; Urtiaga, A.M.; Ortiz, I.; Irabien, J.A. Nanofiltration separation of polyvalent and monovalent anions in desalination brines. J. Membr. Sci. 2015, 473, 16-27. [CrossRef]

27. Vaseghi, G.; Ghassemi, A.; Loya, J. Characterization of reverse osmosis and nanofiltration membranes: Effects of operating conditions and specific ion rejection. Desalination Water Treat. 2016, 57, 23461-23472. [CrossRef]

28. Mao, L.; Tsui, T.-H.; Zhang, J.; Dai, Y.; Tong, Y.W. System integration of hydrothermal liquefaction and anaerobic digestion for wet biomass valorization: Biodegradability and microbial syntrophy. J. Environ. Manag. 2021, 293, 112981. [CrossRef]

29. Tsui, T.-H.; Wong, J.W.C. A critical review: Emerging bioeconomy and waste-to-energy technologies for sustainable municipal solid waste managent. Waste Dispos. Sustain. Energy 2019, 1, 151-167. [CrossRef]

30. Ram, C.; Kumar, A.; Rani, P. Municipal solid waste management: A review of waste to energy (WtE) Approaches. Bioresources 2021, 16, 4275-4320. [CrossRef]

31. Jackowski, M.; Niedzwiecki, L.; Jagiello, K.; Uchanska, O.; Trusek, A. Brewer's spent grains-valuable beer industry by-product. Biomolecules 2020, 10, 1669. [CrossRef]

32. Cheng, C.; Zhu, R.; Thompson, R.G.; Zhang, L.H. Reliability analysis for multiple-stage solid waste management systems. Waste Manag. 2021, 120, 650-658. [CrossRef] 